\title{
Penerapan Sistem Kendali PID pada Antena Pendeteksi Koordinat Posisi UAV
}

\author{
Mahendra Budi Nugraha*1, Raden Sumiharto ${ }^{2}$ \\ ${ }^{1}$ Prodi Elektronika dan Instrumentasi Jurusan Ilmu Komputer dan Elektronika, FMIPA UGM \\ ${ }^{3}$ Jurusan Ilmu Komputer dan Elektronika, FMIPA UGM, Yogyakarta \\ e-mail: *11mahe.bud@gmail.com, ${ }^{2}{ }^{2}$ _sumiharto@ugm.ac.id
}

\begin{abstract}
Abstrak
Pada penelitian ini telah diterapkan sebuah sistem kendali Proporsional-IntegralDerivatif (PID) pada antena pendeteksi koordinat posisi pesawat udara tanpa awak. Sistem kendali PID pada antena pendeteksi digunakan pada kendali gerak horizontal dan vertikal. Nilai acuan kendali PID untuk gerak horizontal adalah sudut azimuth antara antena dan UAV. Sudut tersebut didapatkan dari metode azimuth antara dua buah titik koordinat. Nilai acuan kendali PID untuk gerak vertikal adalah sudut elevasi yang didapat dari metode Haversine Formula dan Sinus Trigonemetri antara jarak dua titik koordinat terhadap ketinggian UAV. Metode tuning PID yang digunakan untuk memperoleh konstanta pengendali PID adalah metode Ziegler-Nichols dengan metode osilasi dan tabel penalaran sistem kendali ZieglerNichols.

Hasil yang diperoleh dari penelitian ini berupa penerapan sistem kendali PID berdasarkan metode Ziegler-Nichols. Sistem kendali berdasarkan tabel penalaran ZieglerNichols divariasikan tiga jenis sistem kendali yaitu P, PI, dan PID. Sistem kendali PD juga diterapkan berdasarkan tabel penalaran Ziegler-Nichols dengan pengendali integral diatur bernilai 0 . Sistem kendali yang memiliki respon paling baik adalah sistem kendali PD dengan nilai $K p=11,375$ dan $K d=0,372531$ untuk kendali azimuth sedangkan kendali elevasi pada nilai $K p=3,41$ dan $K d=0,111464$. Respon yang dihasilkan kendali azimuth sebesar 0,32 detik dan kendali elevasi sebesar 0,34 detik.
\end{abstract}

Kata kunci-PID, Antena Pendeteksi, Servo, UAV

\begin{abstract}
In this project has been implemented a PID control system on antenna tracker of unmanned aerial vehicle coordinates. PID control system on antena tracker to be used on horizontal and vertikal motion control. The setpoint of PID controller for horizontal motion is azimuth's angle between antenna and UAV. The angle produced by azimuth's method between two coordinates. The setpoint of PID controller for vertical motion is elevasi's angle that produced by haversine-formula's method and Sinus Trigonometry between distance two coordinates toward altitude of UAV. Tuning of PID controller was calculated by ZieglerNichols's method with oscillation's method and reasoning table of Ziegler-Nichols.

The result from this project is implementation PID control system with ZieglerNichols's method. There ara 3 variations in Ziegler-Nichols's table, that are P, PI, and PID control system. The PD control system also implemented with integral's control set on 0 . The control system that has a good response is $P D$ control system with $K p=11,375$ and $K d=$ 0,372531 on azimuth's control whereas elevasi's control with $K p=3,41$ and $K d=0,111464$. Response that produced by azimuth's control is 0,32 second and elevasi's control is 0,34 second.
\end{abstract}

Keywords-PID, Antenna Tracker, Servo, UAV

Received November 14 ${ }^{\text {th }}, 2014 ;$ Revised February $20^{\text {th }}, 2015$; Accepted October $1^{\text {th }}, 2015$ 


\section{PENDAHULUAN}

Sistem Unmanned Aerial Vehicle (UAV) memiliki beberapa bagian sistem pembangun, salah $\mathcal{N}$ satunya adalah ground control atau ground segment. Pada pengaplikasian UAV, ground control adalah bagian sistem yang penting sebagai pusat penerima dan pengiriman data yang berhubungan dengan UAV. Keberadaan ground control menjadi suatu keharusan untuk UAV yang bergerak secara autonomous. Data yang biasanya digunakan dalam pengaplikasian UAV seperti air data, altitude, dan heading reference system (ADAHRS) [1].

Komunikasi yang baik dan lancar adalah salah satu komponen pendukung yang dapat menghubungkankan ground control dan UAV. Komunikasi yang digunakan adalah komunikasi nirkabel sehingga dibutuhkan sinyal frekuensi data yang baik untuk memperoleh komunikasi dan hasil pengiriman data yang bagus. Komunikasi yang baik akan memberikan hasil data yang akuran dan real time.

Bagian elektronis pada UAV relatif memiliki ukuran yang kecil dengan daya angkat 0,5 - $5 \mathrm{~kg}$ sehingga harus dibuat seminimal mungkin untuk memperoleh dinamika terbang yang bagus selain pengaruh dari spesifikasi motor penggerak. Pada bagian elektronis UAV sendiri biasanya menggunakan komponen elektronis dengan daya rendah. Komunikasi dengan daya rendah digunakan komunikasi 2,4 GHz modem radio frekuensi seperti XBee atau XStream. Pada modem ini kisaran jarak maksimal yang dapat ditempuh $1-2 \mathrm{~km}$ [2].

Antena menjadi salah satu perangkat pendukung yang penting dalam membangun komunikasi yang baik. Kebanyakan komunikasi radio frekuensi yang digunakan saat ini menggunakan antena omni-directional yang memiliki cakupan area yang luas. Besar kecilnya cakupan area pada antena tersebut tergantung dari spesifikasi antenanya. Kelemahan dari antena jenis ini adalah mudahnya terkena interferensi pada komunikasinya. Interferensi ini akibat banjir data di udara yang muncul dari berbagai sumber sehingga terkadang sering terjadi data lost. Data spesifik yang membutuhkan keakuratan dan data real-time dapat digunakan antena directional yang memiliki jangkauan jauh dengan daya terpusat sehingga interferensinya sangat minimal.

Penggunaan antena directional harus dilengkapi dengan sistem gerakan antena pendeteksi untuk mengikuti posisi koordinat dari UAV. Sistem gerakan antena pendeteksi ini digunakan agar antena tetap dapat berkomunikasi dan menerima data UAV secara real-time. Gerakan yang responsif pada antena pendeteksi membuat data yang diperoleh lebih akurat karena posisi antena akan selalu mengikuti UAV. Sistem kendali dalam gerakan antena adalah sistem yang dapat diterapkan pada antena agar gerakannya lebih responsif. Sistem kendali yang dapat diterapkan salah satunya adalah sistem kendali PID. Sistem kendali PID menganalisis kesalahan yang terjadi pada sistem yang lalu kemudian diproses menjadi sebuah sistem kendali gerakan antena. Berdasarkan masalah dan latar belakang di atas maka dalam penelitian ini akan diimplementasi dan diterapkan sistem kendali PID pada antena pendeteksi terhadap pesawat udara tanpa awak.

\section{METODE PENELITIAN}

\subsection{Analisa Kebutuhan}

Antenna tracker atau antena pendeteksi adalah suatu sistem yang mendeteksi antena utama untuk mengikuti sumber sinyal yang bergerak, seperti satelit komunikasi. Antena tracker digunakan dalam berbagai fungsi seperti aplikasi aero-telemetry, komunikasi point to point dengan basis gerakan, ground system untuk komunikasi UAV, dan lain-lain. Komponen terpenting dalam antena pendeteksi adalah antena yang merupakan antena directional. Antena jenis ini merupakan jenis antena dengan narrow beamwidth, yaitu punya sudut pemancaran 
yang kecil dengan daya lebih terarah, jaraknya jauh dan tidak bisa menjangkau area yang luas[3].

Sistem antena pendeteksi memiliki dua buah gerakan utama yaitu gerakan horizontal dan vertikal. Komponen utama pada antena pendeteksi yaitu GPS receiver dan sensor ketinggian sebagai nilai parameter utama dalam proses pendeteksian UAV. GPS memberikan data berupa posisi baik dari UAV maupun antena sehingga dapat diproses menggunakan metode azimuth yang menghasilkan sudut azimuth untuk gerakan horizontal. Gerakan vertikal menggunakan sudut elevasi yang diperoleh dari jarak antara dua koordinat menggunakan metode haversine formula yang diproses lagi menggunakan aturan sinus trigonometri dengan nilai selisih ketinggian antara UAV dan antena pendeteksi.

\subsection{Rancangan Sistem}

Pada Gambar 1 ditunjukkan rancangan sistem keseluruhan. Sistem antena pendeteksi dibagi dalam dua bagian sistem yaitu sistem ADAHRS sebagai pemberi data dan sistem antena sebagai penerima dan pendeteksi UAV. Sistem ADAHRS (Air Datal Attitude/ Heading Reference System) mengintegrasi data dari sensor seperti sensor GPS, akselerometer, magnetometer, gyrometer, barometer, kompas, dan beberapa sensor lainnya yang ambil bagian pada UAV. Data dari sistem ADAHRS yang digunakan pada sistem antena pendeteksi adalah koordinat posisi dari GPS dan sensor ketinggian dari barometer.

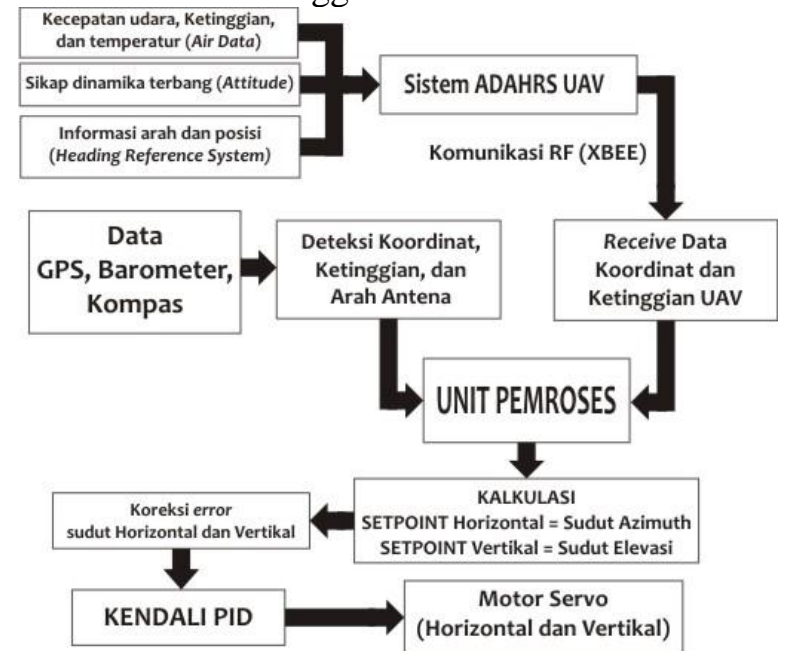

Gambar 1 Diagram blok sistem secara keseluruhan

Unit pemroses dalam sistem antena pendeteksi ini kemudian akan memiliki dua paket data yaitu data ADAHRS UAV dan data antena. Kedua data ini akan diproses menggunakan metode azimuth dan metode haversine formula. Metode azimuth adalah metode untuk memperoleh sudut yang terbentuk dari dua titik koordinat terhadap arah utara. Sudut azimuth yang diperoleh ini akan digunakan sebagai setpoint untuk posisi gerak horizontal. Metode haversine formula berfungsi mencari jarak antara kedua titik koordinat yang mana jarak ini kemudian akan diproses dengan aturan sinus trigonometri sehingga didapati sudut elevasi. Sudut elevasi pada sistem ini akan menjadi setpoint untuk posisi gerakan vertikal.

Sudut-sudut setpoint yang diperoleh akan dibandingkan dengan sudut-sudut antena untuk dilihat besar error yang timbul. Nilai error tersebut yang kemudian akan diproses oleh kendali PID menjadi suatu nilai yang menjadi output untuk motor servo. Respon gerakan antena menuju stabil tergantung dari baik tidaknya nilai-nilai konstanta PID yang diatur pada antena pendeteksi.

\subsection{Rancangan Kendali PID}

Rancangan kendali yang akan diterapkan pada sistem antena pendeteksi menggunakan sistem kendali PID (Proporsional, Integral, dan Derivatif). Metode PID memproses nilai-nilai masukan dari UAV dan mempelajari error yang muncul pada sistem untuk kemudian dilakukan 
kendali PID. Secara konsep dengan metode PID kendali gerakan antena pendeteksi akan dapat berjalan lebih responsif. Diagram blok dari alur kendali PID yang diterapkan pada sistem antena pendeteksi dapat dilihat pada Gambar 2. Pada diagram blok tersebut terdapat dua pembanding utama yaitu setpoint dan proses variabel. Setpoint pada kendali PID adalah sudut yang terbentuk antara antena dan UAV baik azimuth atau elevasi. Sedangkan proses variabel pada sistem adalah posisi arah dari antena menghadap.

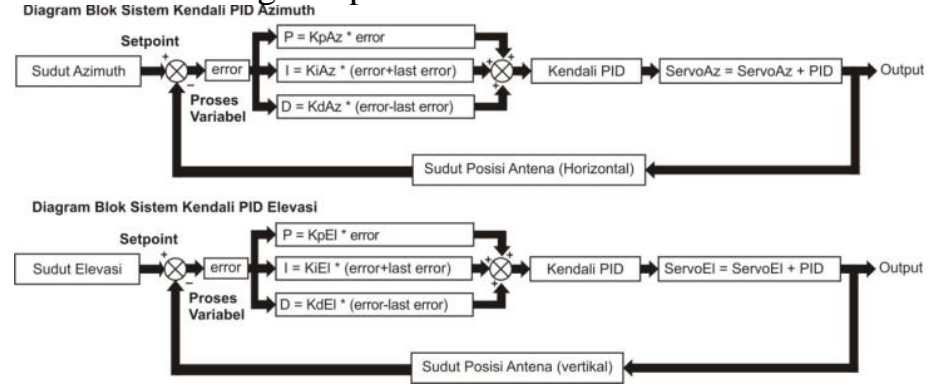

Gambar 2 Diagram blok sistem kendali PID antena pendeteksi

Kedua komponen utama digunakan untuk memperoleh error sistem yang menjadi nilai untuk proses kendali PID. Nilai-nilai PID yang didapatkan akan dikirimkan ke motor servo sebagai sinyal untuk menggerakan antena. Sistem kendali pada antena pendeteksi ini adalah closed loop. Closed loop adalah sistem kontroler umpan balik yang prosesnya terus berulang dengan didapati setpoint tiap satuan loop. Sebuah PID menghitung sebuah nilai "Kesalahan" I "Error" sebagai perbedaan antara variabel proses diukur dan set point yang telah ditentukan. Pengendali akan mencoba untuk meminimalisir kesalahan dengan menyesuaikan input proses control [4].

\subsection{Implementasi}

Antena pendeteksi memiliki dua buah sudut kebebasan atau degree of freedom (DOF) pada gerakan utamanya yaitu gerak horizontal dan vertikal. Perangkat elektronis pada sistem antena pendeteksi ini meliputi implementasi komponen-komponen elektronik seperti GPS receiver, sensor ketinggian, sensor kompas elektronik, modul komunikasi, dan aplikasi motor servo. Semua komponen-komponen elektronik tersebut terintegrasi ke dalam suatu unit pengolah data atau mikrokontroler. Mikrokontroler pada sistem antena pendeteksi berfungsi sebagai pusat pengolah data, baik konfigurasi sistem maupun proses kendali PID. Gambar 3 merupakan implementasi antena pendeteksi secara menyeluruh.

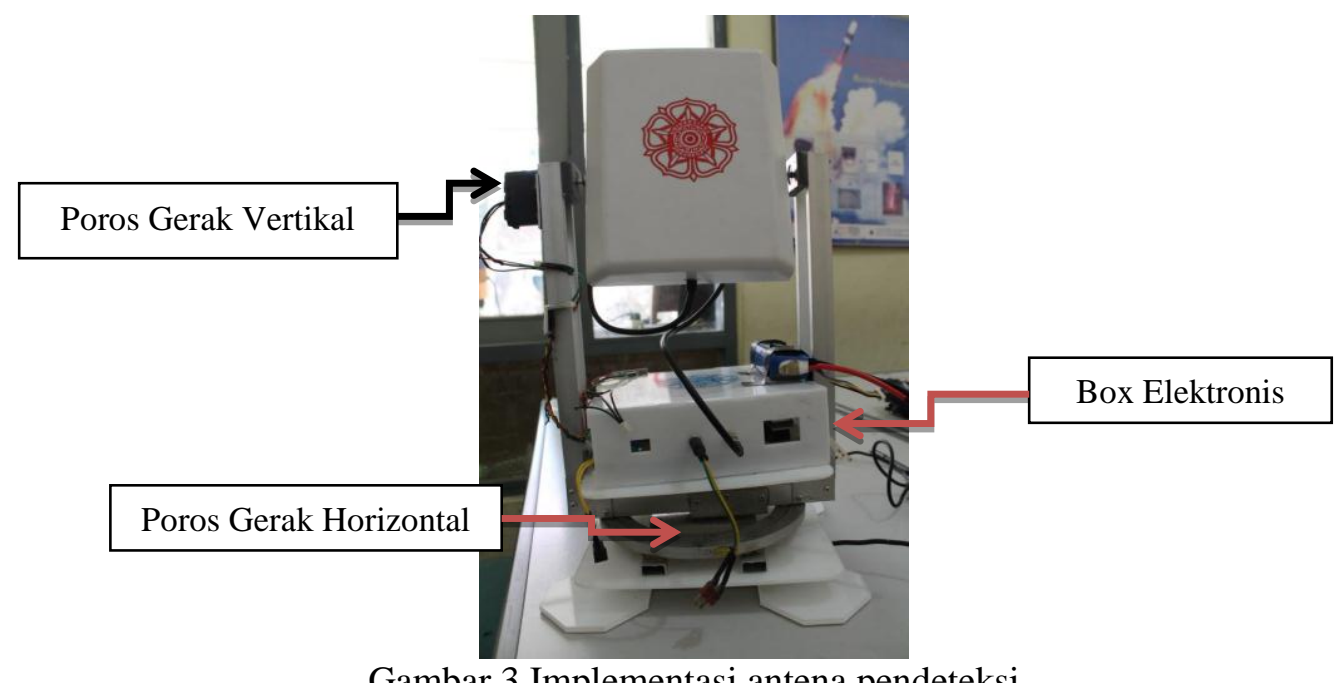

Gambar 3 Implementasi antena pendeteksi

IJEIS Vol. 5, No. 2, October 2015 : 187 - 198 
Kendali PID mendeteksi nilai error yang dihasilkan sistem untuk mencapai sebuah kestabilan yang error-nya didapatkan dari pengurangan nilai setpoint dengan variabel proses. Setpoint pada sistem PID ini adalah posisi UAV yang dideteksi. Antena pendeteksi memiliki dua buah sudut kebebasan (DOF) sehingga dari setpoint tersebut terbagi dua yaitu setpoint azimuth dan elevasi. Setpoint azimuth didapat dari kalkulasi metode azimuth untuk dua posisi yang berbeda. Hasil yang diperoleh dari metode ini adalah sudut yang dihasilkan posisi UAV terhadap arah utara. Setpoint didapat dari kalkulasi metode haversine formula. Metode tersebut menghitung jarak antara dua koordinat posisi dalam hal ini antena dan UAV. Jarak yang didapat tersebut kemudian dikalkulasi lagi dengan metode sinus trigonometri untuk mendapatkan sudut kemiringan antena terhadap UAV.

\subsection{Tuning PID}

Metode tuning PID yang digunakan menggunakan metode Ziegler-Nichols. Metode ini memiliki dua cara, yaitu metode osilasi dan kurva reaksi. Metode Ziegler-Nichols yang digunakan adalah metode osilasi. Metode osilasi adalah metode penalaran yang didasarkan pada reaksi sistem loop tertutup. Plant pada metode ini disusun serial dengan kontroler PID yang parameter integratornya diatur tak terhingga sedangkan parameter diferensialnya diatur nol (Ti $=\sim ; \mathrm{Td}=0$ ). Metode ini dilakukan dengan cara parameter proporsional dinaikkan bertahap hinggap mencapai reaksi sistem yang berosilasi. Pada metode osilasi terdapat nilai penguatan saat mencapai kondisi osilasi yaitu ultimate gain $\mathrm{K}_{\mathrm{u}}$. Periode saat terjadi tersebut disebut ultimate period $\mathrm{P}_{\mathrm{u}}$. Konstantan PID didapatkan berdasarkan model penalaran pada Tabel 1 [5].

Tabel 1 Model penalaran parameter PID dengan metode osilasi

\begin{tabular}{|c|c|c|c|}
\hline $\begin{array}{c}\text { Tipe } \\
\text { Kontrol }\end{array}$ & $\boldsymbol{K p}$ & $\boldsymbol{K i}$ & $\boldsymbol{K} \boldsymbol{d}$ \\
\hline $\boldsymbol{P}$ & $0,50 \mathrm{Ku}$ & - & - \\
\hline $\boldsymbol{P I}$ & $0,45 \mathrm{Ku}$ & $1,2 \mathrm{Kp} / \mathrm{Pu}$ & - \\
\hline $\boldsymbol{P I D}$ & $0,60 \mathrm{Ku}$ & $2 \mathrm{Kp} / \mathrm{Pu}$ & $\mathrm{KpPu} / 8$ \\
\hline
\end{tabular}

Tuning PID dilakukan untuk dua buah kendali PID yang ada pada sistem antena pendeteksi yaitu kendali PID azimuth dan elevasi. Kendali PID azimuth adalah kendali yang bekerja pada gerakan horizontal antena pendeteksi, sedangkan kendali PID elevasi bekerja pada gerakan vertikal antena pendeteksi. Pengujian dilakukan terhadap ADAHRS dengan posisi yang tetap dan antena pendeteksi yang diberi nilai konstanta Kp secara bertahap.

\section{HASIL DAN PEMBAHASAN}

\subsection{Pengujian Metode Ziegler-Nichols Kendali PID}

Tuning PID dilakukan untuk dua buah kendali PID yang ada pada sistem antena pendeteksi yaitu kendali PID azimuth dan elevasi. Kendali PID azimuth adalah kendali yang bekerja pada gerakan horizontal antena pendeteksi, sedangkan kendali PID elevasi bekerja pada gerakan vertikal antena pendeteksi. Pada tuning azimuth, sistem tidak stabil pada konstanta Kp bernilai 23 sehingga harus diturunkan nilai Kp-nya dan didapati nilai Kp sebesar 22,75 untuk sistem yang berosilasi konstan. Pada tuning PID elevasi, sistem mulai tidak stabil pada konstanta Kp bernilai 7 . Nilai konstanta $\mathrm{Kp}$ untuk sistem yang berosilasi konstan didapati sebesar 6,82. Hasil $\mathrm{Kp}$ tersebut menghasilkan nilai $\mathrm{Ku}$ dan $\mathrm{Pu}$ yang dapat ditunjukkan pada Tabel 2.

Tabel 2 Hasil nilai Ku dan Pu metode Ziegler-Nichols

\begin{tabular}{|c|c|c|}
\hline Konstanta & Azimuth & Elevasi \\
\hline $\boldsymbol{K u}$ & 22,75 & 6,82 \\
\hline $\boldsymbol{P u}$ & 0,262 detik & 0,2615 detik \\
\hline
\end{tabular}




\subsection{Pengujian Statis Kendali PID Antena Pendeteksi}

Pengujian statis kendali PID antena pendeteksi adalah pengujian untuk mengetahui pengaruh nilai konstanta $\mathrm{Kp}$, Ki dan $\mathrm{Kd}$ terhadap sistem yang dilakukan untuk posisi setpoint diam. Nilai konstanta Kp, Ki dan Kd yang diatur pada sistem ini ditentukan dari penentuan nilai $\mathrm{Ku}$ dan $\mathrm{Pu}$ pada pengujian sebelumnya. Pengujian statis ini dibagi menjadi dua yaitu untuk kendali PID statis azimuth dan elevasi. Nilai Ku dan Pu dikalkulasikan menurut tabel penalaran metode Ziegler-Nichols yang ditunjukkan pada Tabel 3.

Tabel 3 Konstanta PID Metode Ziegler-Nichols

\begin{tabular}{|c|c|c|c|c|c|c|}
\cline { 2 - 7 } \multicolumn{1}{c|}{} & \multicolumn{3}{c|}{ Azimuth } & \multicolumn{3}{c|}{ Elevasi } \\
\hline $\begin{array}{c}\text { Tipe } \\
\text { Kontrol }\end{array}$ & $K p$ & $K i$ & $K d$ & $K p$ & $K i$ & $K d$ \\
\hline $\boldsymbol{P}$ & 11,375 & - & - & 3,41 & - & - \\
\hline $\boldsymbol{P I}$ & 10,2375 & 46,889313 & - & 3,069 & 14,08337 & - \\
\hline $\boldsymbol{P I D}$ & 13,65 & 104,198473 & 0,447038 & 4,092 & 31,29637 & 0,133757 \\
\hline
\end{tabular}

Pada penelitian ini didapati sebuah hasil bahwa adanya kendali integral menjadikan sistem tidak stabil. Kendali PI maupun PID bereaksi pada perubahan secara tiba-tiba pada sinyal error yang konstan. Kendali integral mampu menghasilkan keluaran pengontrol meskipun sinyal error-nya 0. Aktuator pada antena pendeteksi bekerja berbanding lurus dengan sinyal error sehingga untuk sebuah keluaran pengontrol tidak akan mengubah sinyal error secara kontinyu. Pada Gambar 4 ditunjukkan hasil grafik kestabilan dari kendali yang memiliki komponen integral yang menghasilkan sistem yang tidak stabil.
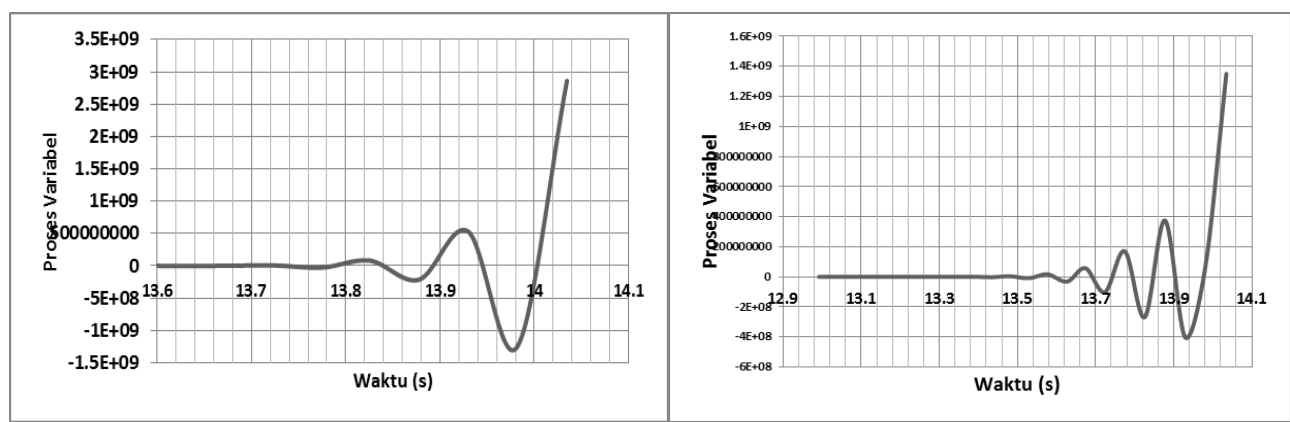

Gambar 4 Grafik kestabilan dengan kendali Integral

Kendali PID yang dapat diterapkan pada antena pendeteksi menurut metode ZieglerNichols hanya kendali proporsional sehingga dilakukan variasi tabel Ziegler-Nichols. Variasi ini dilakukan dengan memberikan tiga macam kendali Proporsional-Derivatif (PD) dengan nilai konstanta yang berbeda-beda. Kendali ini bekerja pada laju perubahan error yang terjadi dalam satuan waktu. Pada saat terjadi perubahan error makan pengendali ini akan bekerja sedangkan pada saat error konstan maka pengendali ini tidak akan memberikan keluaran apapun. Pada Tabel 4 merupakan hasil konstanta menurut tabel penalaran Ziegler-Nichols yang divariasi.

Tabel 4 Konstanta PD Variasi Metode Ziegler-Nichols

\begin{tabular}{|c|c|c|c|c|c|c|}
\cline { 2 - 7 } \multicolumn{1}{c|}{} & \multicolumn{3}{c|}{ Azimuth } & \multicolumn{3}{c|}{ Elevasi } \\
\hline $\begin{array}{c}\text { Tipe } \\
\text { Kontrol }\end{array}$ & $K p$ & $K i$ & $K d$ & $K p$ & $K i$ & $K d$ \\
\hline$P D 1$ & 13,65 & - & 0,447038 & 4,092 & - & 0,133757 \\
\hline$P D 2$ & 11,375 & - & 0,372531 & 3,41 & - & 0,111464 \\
\hline$P D 3$ & 10,2375 & - & 0,335278 & 3,069 & - & 0,100318 \\
\hline
\end{tabular}


Variasi kendali PID yang diuji berjumlah 4 macam kendali yaitu kendali proposional dan proposional derivatif 1,2 , dan 3. Keempat macam kendali tersebut dilihat karakteristiknya sehingga diperoleh respon terbaik untuk gerakan antena pendeteksi. Respon terbaik dari empat macam kendali tersebut adalah kendali PD 2 dimana memiliki nilai Kp 11,375 dan Kd 0,372531 untuk kendali azimuth dan nilai Kp 3,41 dan 0,111464 untuk kendali elevasi.. Hasil ini ditunjukkan oleh Tabel 5 yang merupakan hasil respon sistem secara keseluruhan.

Tabel 5 Hasil respon sistem kendali PID statis

\begin{tabular}{|c|c|c|}
\hline Kendali & Respon Azimuth & Respon Elevasi \\
\hline Proposional & 4,68 milidetik & 4,68 milidetik \\
\hline Proporsional-Derivatif 1 & 36,23 milidetik & 36,23 milidetik \\
\hline Proporsional-Derivatif 2 & 4,5 milidetik & 4,1 milidetik \\
\hline Proporsional-Derivatif 3 & 182,4 milidetik & 182,392 milidetik \\
\hline
\end{tabular}

Pada Gambar 5, grafik kestabilan kendali PD 2 azimuth dihasilkan nilai settling-time sebesar 98,504 milisekon yang merupakan lama waktu sistem untuk mencapai kestabilan pada nilai setpoint. Respon sistem berdasarkan nilai rise-time yang dihasilkan sebesar 4,5 milisekon. Nilai tersebut lebih besar daripada respon yang dimiliki kendali proporsional karena nilai gain proporsionalnya sama besar namun pada kendali ini diveri pengendali derivatif sehingga responnya lebih cepat. Stabilitas relatif pada sistem ini sebesar 7,66 yang merupakan maksimum overshoot dari sistem kendali PD ini.

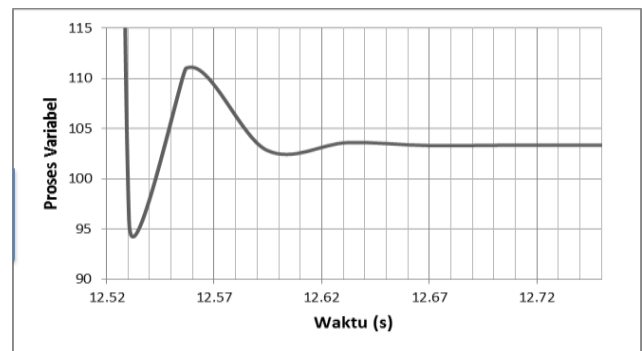

Gambar 5 Grafik kestabilan kendali Proposional-Derivatif 2 Azimuth

Sedangkan pada kendali PD 2 elevasi, sistem ini memerlukan waktu selama 98,504 detik untuk mencapai kestabilan pada nilai setpoint yang ditunjukkan pada Gambar 6. Respon yang diperoleh dengan sistem kendali PD ini lebih cepat karena terdapat pengendali derivatif yang mengoreksi laju perubahan error sehingga menghasilkan respon yang lebih baik. Pada sistem ini didapati nilai maksimum overshoot yang berarti adalah stabilitas relatif dari sistem sebesar 1,02. Apabila dilihat berdasarkan analisis step responya, sistem ini termasuk dalam sistem kritis teredam atau critically damped.

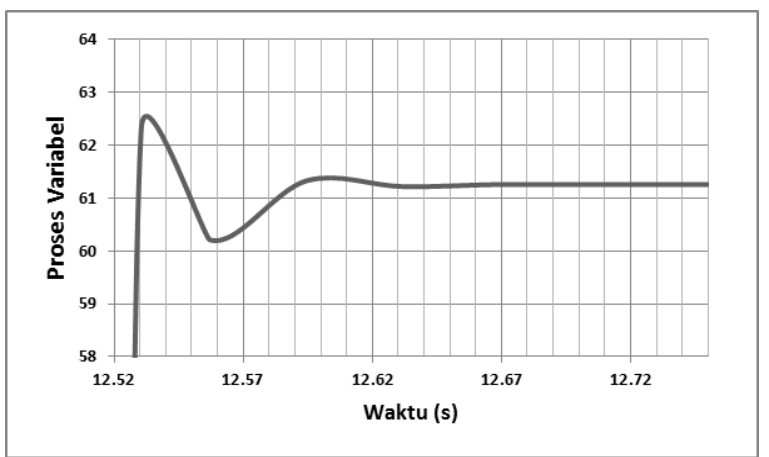

Gambar 6 Grafik kestabilan kendali Proposional-Derivatif 2 Elevasi 


\subsection{Pengujian Dinamis Kendali PID Antena Pendeteksi}

Pengujian dinamis kendali PID bertujuan menguji sistem kendali terhadap respon sistem antena untuk mendeteksi setpoint yang bergerak yaitu UAV. Pengujian ini berdasarkan pada variasi-variasi sistem kendali yang telah dilakukan pada pengujian statis. Kendali PID dinamis terbagi menjadi dua yaitu kendali PID dinamis untuk azimuth dan elevasi. Kendali dinamis azimuth adalah kendali gerakan antena pendeteksi untuk obyek yang bergerak secara horizontal. Kendali dinamis elevasi bekerja pada gerakan antena untuk obyek yang bergerak secara vertikal.

Kendali PID yang diuji pada kendali dinamis ada 4 variasi yaitu proporsional dan proporsional-derivatif 1,2 , dan 3. Nilai konstanta yang diatur pada antena pendeteksi sesuai dengan yang ditunjukkan oleh Tabel 3 dan 4 . Hasil yang diperoleh dari pengujian ini berupa respon sistem yang dihasilkan antena pendeteksi menurut grafik yang dihasilkan. Respon sistem kendali PID secara keseluruhan untuk kendali azimuth dan elevasi ditunjukkan oleh Tabel 6.

Tabel 6 Hasil respon sistem kendali PID dinamis

\begin{tabular}{|c|c|c|}
\hline Kendali & Respon Azimuth & Respon Elevasi \\
\hline Proposional & 0,38 detik & 0,38 detik \\
\hline Proporsional-Derivatif 1 & 0,49 detik & 0,35 detik \\
\hline Proporsional-Derivatif 2 & 0,32 detik & 0,34 detik \\
\hline Proporsional-Derivatif 3 & 0,51 detik & 0,42 detik \\
\hline
\end{tabular}

Kendali dinamis azimuth menggunakan sistem pengendali proporsional pada nilai konstanta sebesar 11,375 yang grafik kestabilannya ditunjukkan pada Gambar 7. Respon dari sistem antena pendeteksi dalam mendeteksi suatu koordinat posisi ke koordinat posisi lainnya selama 0,38 detik. Karakteristik dari sistem kendali proporsional yang tampak dari grafik tersebut adalah pada deteksi perpindahan posisi yang relatif konstan tiap satuan waktu tertentu. Besar kecilnya waktu itu dipengaruhi oleh kecepatan UAV atau pembacaan koordinat dari GPS. Sistem kendali ini akan memberikan sinyal pengendali untuk suatu data tertentu dan memproses kembali ketika terdapat data posisi yang baru.

Kendali dinamis elevasi dengan sistem kendali proporsional menggunakan nilai konstanta proporsional sebesar 3,41 yang grafik kestabilannya ditunjukkan pada Gambar 7. Respon yang dihasilkan oleh sistem kendali ini sekitar 0,38 detik namun yang membedakan adalah pada perubahan data yang terjadi. Koreksi data ketinggian UAV yang mencapai ukuran centimeter membuat koreksi sudut setpoint yang dihasilkan lebih presisi. Karakteristik pola yang terbentuk pada grafik menunjukkan bahwa pengendali proporsional elevasi memiliki karakteristik sama dengan proporsional azimuth dengan waktu untuk mencapai kestabilan relatif konstan.

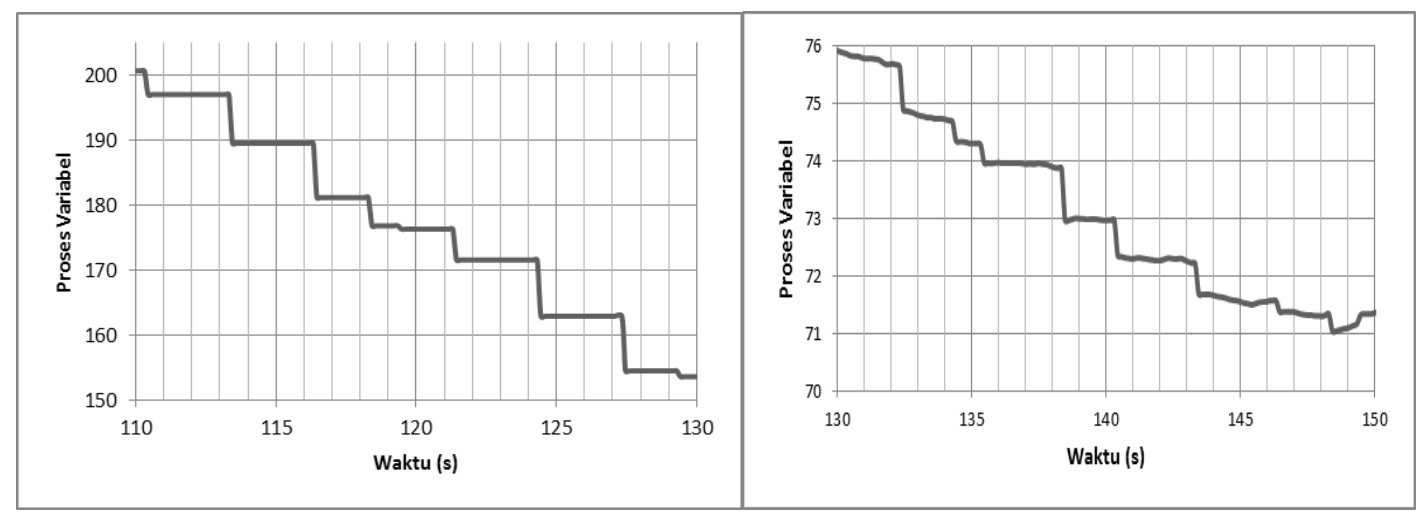

Gambar 7 Grafik kestabilan sistem kendali P dinamis azimuth (ka) dan elevasi (ki) 
Sistem kendali proporsional-derivatif azimuth variasi pertama menggunakan nilai konstanta proporsional sebesar 13,65 dan derivatif sebesar 0,447038 yang grafik kestabilannya ditunjukkan pada Gambar 8. Respon sistem yang dapat dilihat dari grafik tersebut menunjukkan nilai sebesar 0,49 detik. Waktu tersebut terhitung dari saat sistem mendeteksi posisi hingga terjadi overshoot. Karakteristik dari sistem kendali ini memungkinkan adanya perpindahan posisi ketika sistem belum mencapai kestabilan. Hal ini disebabkan karena sistem kendali ini memiliki gain yang cukup besar sehingga membuat sistem menghasilkan nilai maksimum overshoot yang besar juga. Nilai overshoot yang besar itu akan berpengaruh pada settling-time yang lebih lama sehingga sebelum sistem mencapai kestabilan sudah didapati data setpoint baru untuk diproses.

Pengendali proporsional-derivatif elevasi variasi pertama yang diterapkan menggunakan nilai konstanta $\mathrm{Kp}$ sebesar 4,092 dan $\mathrm{Kd}$ sebesar 0,133757 yang grafik kestabilannya ditunjukkan pada Gambar 8. Respon yang dihasilkan dari sistem kendali ini sekitar 0,35 detik untuk nilai yang merupakan respon saat antena mendeteksi posisi hingga sinyal pengendali bekerja. Sistem ini sangat responsif untuk digunakan pada deteksi UAV untuk perubahan data yang cepat. Perubahan data yang cepat diakibatkan oleh manuver UAV yang naik atau turun dengan kecepatan tinggi. Pada saat sistem mengalami overshoot, sistem dapat memproses data setpoint yang baru sehingga untuk arah manuver konstan dengan kecepatan tinggi pun sistem kendali dapat bekerja responsif.
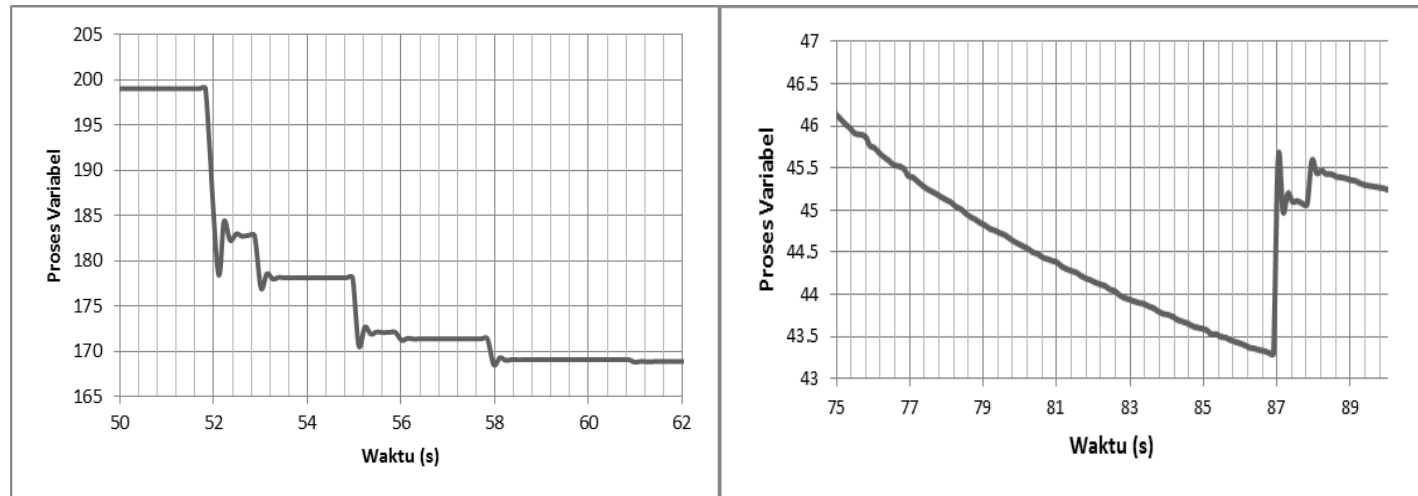

Gambar 8 Grafik kestabilan sistem kendali PD 1 dinamis azimuth (ka) dan elevasi (ki)

Variasi sistem kendali proporsional-derivatif azimuth kedua yang diterapkan menggunakan nilai konstanta $\mathrm{Kp}$ sebesar 11,375 dan $\mathrm{Kd}$ sebesar 0,372531 yang grafik kestabilannya ditunjukkan pada Gambar 9. Sistem kendali PD memberikan respon selama 0,32 detik. Sistem ini cukup responsif melihat settling-time-nya cepat ditambah pula rise-time yang cepat. Pada grafik kestabilan sekilas terlihat memiliki karakteristik yang sama dengan pengendali proporsional. Hal ini dikarena nilai konstanta Kp yang diatur sama besasr sedangkan pada sistem ini diberi pengendali derivatif. Fungsi pengendali derivatif bagi pengendali proporsional untuk memperhalus dan mempercepat respon kendali karena pengendali derivatif bekerja pada perubahan error yang terjadi di sistem. Hal ini terlihat pada grafik kestabilan untuk deteksi perpindahan posisi UAV terjadi pada rentang waktu yang berbeda-beda. Karakteristik lain dari sistem kendali ini adalah dapat berada pada posisi yang stabil dengan cepat sebelum memproses data masukan yang baru. 


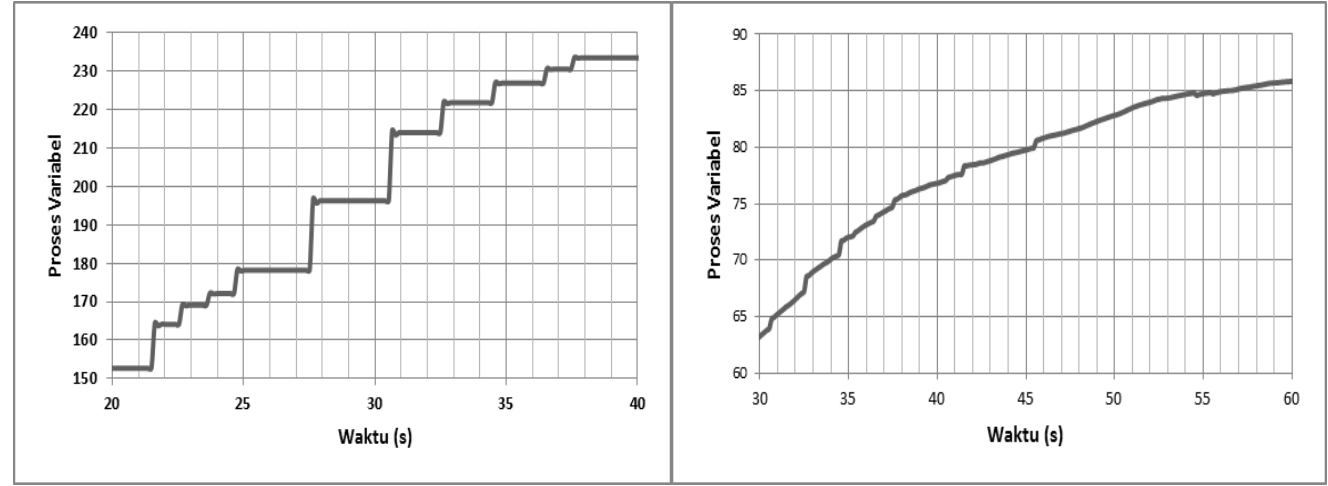

Gambar 9 Grafik kestabilan sistem kendali PD 2 dinamis azimuth (ka) dan elevasi (ki)

Variasi pengendali proporsional-derivatif elevasi yang kedua menggunakan nilai konstanta Kp sebesar 3,41 dan Kd sebesar 0,111464 yang grafik kestabilannya ditunjukkan pada Gambar 9. Respon yang dihasilkan oleh sistem kendali ini sekitar 0,34 detik. Karakteristik yang menarik dari apa yang ditunjukkan oleh grafik kestabilan adalah kecenderungan arah kendali sistem yang terjadi. Sistem ini memiliki pengendali yang lebih halus dari pada pengendali PD sebelumnya. Pada manuver UAV baik ke atas maupun ke bawah sistem kendali ini memberikan stabilitas yang relatif sama. Pada saat UAV bermanuver ke bawah grafik sistem kendali akan mengikuti kecenderungan arah sistem yang bekerja sehingga kestabilan yang muncul tidak konstan mendatar namun menuju arah gerak perubahan data UAV. Hal ini disebabkan karena stabilitas pada sistem ini relatif konstan dengan nilai maksimum overshoot yang tidak begitu besar. Selain sudah memperoleh kestabilan, sistem dapat dengan cepat mendeteksi data setpoint baru untuk diproses lagi.

Sistem kendali proporsional-derivatif azimuth variasi ketiga menggunakan nilai konstanta proporsional sebesar 10,2375 dan derivatif sebesar 0,335278 yang grafik kestabilannya ditunjukkan pada Gambar 10. Pada pengujian statis sistem kendali ini memiliki respon yang lambat karena tidak memiliki nilai overshoot lamanya waktu settling time dibandingkan dengan pengendali lainnya. Respon dari sistem kendali ini apabila diukur dari waktu terdeteksi posisi sampai dengan sistem pada titik nilai setpoint selama 0,51 detik. Penyebab dari lambatnya respon dari sistem kendali PD ini adalah kurangnya gain atau nilai konstanta terutama pada konstanta proporsional. Sistem dengan pengendali proporsional bernilai gain tersebut memiliki settling time yang lama sehingga ketika diberi pengendali derivatif maka justru akan membuat sistem lebih halus. Dilihat dari grafik kestabilan yang dihasilkan, sistem kendali ini dapat diterapkan untuk UAV berkecepatan rendah sehingga respon dari sistem ini tetap dapat mengikui perubahan posisi yang tidak terlalu cepat.

Pengendali proporsional-derivatif terakhir yang divariasikan menggunakan nilai konstanta Kp sebesar 3,069 dan Kd sebesar 0,100318 yang grafik kestabilannya ditunjukkan pada Gambar 10. Respon sistem yang dihasilkan oleh pengendali ini sekitar kurang lebih 0,42 detik pada respon yang diperoleh saat antena mendeteksi data setpoint menuju sistem yang stabil. Seperti hasil yang diperoleh dari pengujian statis, sistem kendali ini memiliki respon yang lambat dikarenakan tidak adanya overshoot yang muncul. Efek yang ditimbulkan akibat respon yang lambat adalah gerakan antena kurang responsif untuk menuju setpoint yang diperoleh. 


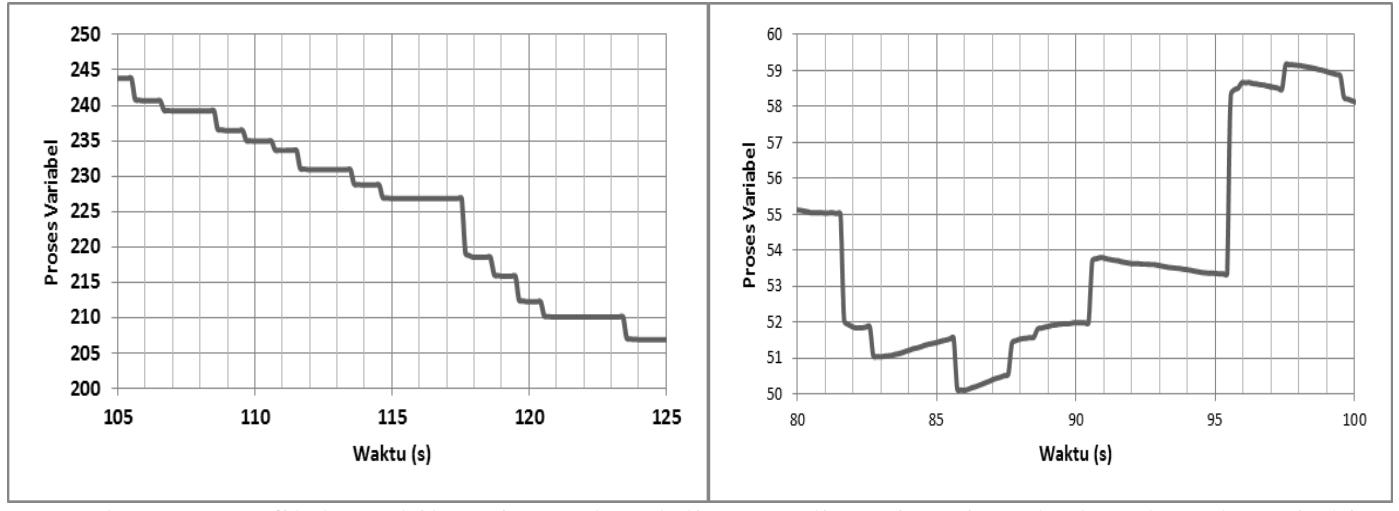

Gambar 10 Grafik kestabilan sistem kendali PD 2 dinamis azimuth (ka) dan elevasi (ki)

\section{KESIMPULAN}

1. Nilai konstanta ultimate gain $(\mathrm{Ku})$ dan periode osilasi $(\mathrm{Pu})$ pada sistem kendali gerak antena pendeteksi horizontal sebesar 22,75 dan 0,262 detik.

2. Nilai konstata ultimate gain $(\mathrm{Ku})$ dan periode osilasi $(\mathrm{Pu})$ pada sistem kendali gerak antena pendeteksi vertikal sebesar 3,41 dan 0,2615 detik.

3. Pengendali integral menurut metode penalaran Ziegler-Nichols tidak cocok diterapkan pada antena pendeteksi.

4. Sistem kendali proporsional-derivatif (PD) pada gerak horizontal antena pendeteksi posisi merupakan kendali yang terbaik dengan respon selama 0,32 detik untuk nilai $\mathrm{Kp}=11,372$ dan $\mathrm{Kd}=0,372531$.

5. Sistem kendali proporsional-derivatif (PD) pada gerak vertikal antena pendeteksi posisi merupakan kendali yang terbaik dengan nilai $\mathrm{Kp}=3,41$ dan $\mathrm{Kd}=0,111464$ yang memiliki respon selama 0,34 detik.

6. Pada penelitian ini didapati kendali derivatif pada proporsional-derivatif memberikan efek yang lebih baik pada sistem kendali antena pendeteksi karena sistem mampu mengoreksi kecepatan perubahan nilai koreksi yang terjadi sehingga sistem mampu bekerja lebih responsif.

\section{SARAN}

Pada penelitian ini digunakan sistem kendali PID sebagai kendali penuh gerakan antena, untuk penelitian selanjutnya dapat diterapkan metode prediksi yang mempertimbangkan kecepatan manuver dari UAV sehingga diharapkan antena dapat mendeteksi posisi UAV lebih cepat.

\section{UCAPAN TERIMA KASIH}

Penulis mengucapkan terima kasih kepada PPKI UGM yang telah memberi dukungan financial terhadap penelitian ini. 


\section{DAFTAR PUSTAKA}

[1] Manggala, A. P., 2012, Purwarupa Air Data, Attitude, And Heading Reference System untuk Pesawat Terbang Tanpa Awak Sayap Tetap. Skripsi FMIPA Universitas Gadjah Mada: Yogyakarta.

[2] Stojcsics, D. dan Somlyai L., 2010, Improvement Methods of Short Range and Low Bandwidth Communication for Small Range UAV, IEEE 8th International Symposium on Intelligent System and Informatics, Subotica, Serbia.

[3] Wicaksono, G. E., 2013, Purwarupa Sistem Kendali Gerak Antena Pendeteksi Terhadap Koordinat Posisi Pesawat Udara Tanpa Awak. Skripsi Fakultas MIPA Universitas Gadjah Mada: Yogyakarta.

[4] Iswara, P. J., 2012, Sistem Kontrol Keseimbangan Statis Robot Humanoid Joko Klana Berbasis Pengontrol PID. Skripsi FMIPA Universitas Gadjah Mada: Yogyakarta.

[5] Ogata, K., 2010, Modern Control Engineering Fifth Edition, Prentice Hall: New Jersey. 